Collection: IUFRO RG 7.01 (2010) - Antalya (Turkey)

Adaptation of Forest Ecosystems to Air Pollution and Climate Change

Guest Editors: Elena Paoletti, Yusuf Serengil

\section{Changes in the proteome of juvenile European beech following three years exposure to free-air elevated ozone}

\author{
Kerner $\mathrm{R}^{(1-2)}$, Winkler JB ${ }^{(4)}$, Dupuy $\mathrm{JW}^{(3)}$, Jürgensen $\mathrm{M}^{(2)}$, \\ Lindermayr $C^{(2)}$, Ernst $D^{(2)}$, Müller-Starck $G^{(1)}$
}

Tropospheric ozone, one of the most phytotoxic air pollutants, may specially impose in long-lived forest trees substantial reduction in productivity and biomass. European beech saplings grown in lysimeter around areas were used to monitor proteomic changes upon elevated ozone concentrations following four vegetation periods of exposure. A proteome study based on highly sensitive two-dimensional fluorescence difference gel electrophoresis (2-D DIGE) was performed to identify protein changes in European beech, the most important deciduous tree in Central Europe. Main emphasis was on identifying differentially expressed proteins after long-time period of ozone exposure under natural conditions rather than short-term responses or reactions under controlled conditions. Our results clearly demonstrate a response of European beech saplings to long-term ozone fumigation at the protein level. We indicate changes in the protein abundance of 142 protein spots; among them 59 were increased and 83 decreased following three years of elevated ozone exposure. As the first step, $\mathbf{4 0}$ proteins were identified by a homology driven mass spectrometric approach. Some of the identified proteins have been previously described in the context of short-term ozone responses in plants, indicating, at least for certain cellular functions, the congruence of plant reactions following shortand long-term ozone exposure. Under elevated ozone exposure, abundance of proteins related to the Calvin cycle and photosynthetic electron transport chain were decreased whereas the abundance of proteins regarding the carbon metabolism/catabolism were increased.

Keywords: Abiotic stress, Elevated ozone, European beech, Woody plants, 2-D DIGE

\section{Introduction \\ Tropospheric ozone, as an indirectly emit- ted greenhouse gas, is present in low concen- trations, but minor changes in its abundance seem to have strong influences on living organisms. Mainly due to anthropogenic pol- lutants, such as those from biomass and fossil fuel burning, ground levels of ozone concentrations have more than doubled in the past 100 years (Hough \& Derwent 1990 , Marenco et al. 1994). Due to its powerful oxidizing properties and consequently its capability of damaging organic molecules, ozone has been well known to be detrimental for living organisms. In plants, ozone enters through the stomata, triggering a reactive oxygen species reaction in the apoplast of leaves (Sandermann 1996, Pell et al. 1997). The type and severity of injury can vary de- pending on concentration, weather condi- tions, length of exposure and genetical pre- disposition of plants.}

(1) Section of Forest Genetics, Technische Universität München, Hans-Carlvon-Carlowitz-Platz 2, D-85354 Freising (Germany); (2) Institute of Biochemical Plant Pathology, Helmholtz Zentrum München, Ingolstädter Landstr. 1, D-85764 Neuherberg (Germany); (3) Université de Bordeaux, Centre de Génomique Fonctionnelle Bordeaux, Plateforme Protéome, F-33000 Bordeaux (France); (4) Department of Environmental Engineering, Helmholtz Zentrum München, Ingolstädter Landstr. 1, D-85764 Neuherberg (Germany).

@ René Kerner (kerner@wzw.tum.de)

Received: Sep 13, 2010 - Accepted: Jan 17, 2011

Citation: Kerner R, Winkler JB, Dupuy JW, Jürgensen $M$, Lindermayr $C$, Ernst $D$, MüllerStarck G, 2011. Changes in the proteome of juvenile European beech following three years exposure to free-air elevated ozone. iForest 4: 69-76 [online: 2011-04-06] URL: http://www.sisef.it/ iforest/show.php? id $=570$

\section{al. 2009).}

During the last years the use of proteomics in plant biology research has increased significantly (Jorrín-Novo et al. 2009), however, there is still very little information available in terms of proteomic analysis after longterm responses to ozone and even less for field experiments in woody plants upon this hazardous oxidant. Although seven previous proteomic studies in plant species have provided valuable insights into ozone-related protein expression, those reports have focused on short-time periods of ozone exposure under controlled conditions (Agrawal et al.

Box 1 - List of abbreviations.

Exposure to ozone has been linked to a number of altering effects in plants, including reduced growth, lower yields, accelerated senescence and necrosis in leaf tissue (Matyssek et al. 1993,Örvar et al. 1997, Pell et al. 1997). At the physiological and biochemical level ozone has been shown to decline gas exchange (Kronfuß et al. 1998) and to inhibit carboxylation efficiency and net photosynthesis (Dizengremel 2001, Agrawal et al. 2002, Bohler et al. 2007, Ryang et al. 2009). Different studies have also shown an induction of glucose catabolism, mitochondrial respiration as well as activation of detoxification and reparation processes (Bohler et al. 2007, He et al. 2007). For the same material as in this experiment it was recently shown at the transcript level that several expressed sequence tags (ESTs) involved in cell structure, related to stress response and cell walls, signal transduction, as well as disease and defence were induced (Olbrich et
- 2-D DIGE: two-dimensional fluorescence difference gel electrophoresis

- ACN: acetonitrile

- AOT 40: accumulated exposure over a threshold of $40 \mathrm{ppb}$

- ATP: adenosine triphosphate

- BSA: bovine serum albumin

- CBB: colloidal Coomassie G-250

- DCn: delta correlation value

- ESTs: expressed sequence tags

- IEF: isoelectric focusing

- LC-MS/MS: liquid chromatographictandem mass spectrometry

- MS/MS: tandem mass spectrometry

- Mw: molecular weight

- NaOH: Sodium hydroxide

- pI: isoelectric point

- RuBisCO: ribulose-1.5-bisphosphate carboxylase/oxygenase

- TCA: tricarboxylic acid cycle

- TRIS: tris(hydroxymethyl)-aminomethan 
2002, Bohler et al. 2007, Torres et al. 2007, Cho et al. 2008, Feng et al. 2008, Ahsan et al. 2010, Sarkar et al. 2010). The overall aim of this investigation was to study long-time effects of elevated ozone under natural conditions in European beech trees, the most imEurope.

Here we present for the first time a proteomic approach using highly sensitive two-dimensional fluorescence difference gel electrophoresis (2-D DIGE) coupled with a homology driven mass spectrometric approach in order to identify local changes in leaf proteins from European beech saplings following three years ozone fumigation, covering two entire and two partial vegetation periods. Furthermore we used complementary transcript results performed on the same study (Olbrich et al. 2009) as well as starch and sucrose results (Fleischman et al. 2009) from beech saplings grown in lysimeters of this experiment, in order to better understand ozone related responses on the molecular level.

\section{Material and methods}

\section{Experimental design}

The experimental design of the lysimeter and its surrounding area including the freeair ozone exposure device was previously described (Schloter et al. 2005, Pritsch et al 2008, Winkler et al. 2009). In brief, fores soil from the forest site "Högelwald" was filled in and around lysimeters in 1999. For the subsequent three years soil was left untreated to ensure the development of a typical soil structure. In November 2002, threeyear-old nursery grown European beech saplings were planted in and around lysimeters. Ambient and twice ambient ozone fumigation started in July 2003 and ended after four vegetation periods in August 2006. Ozone was fumigated during the day period and stopped for the first vegetation period in December 2003. For the year 2004 and 2005, portant deciduous tree species in Central

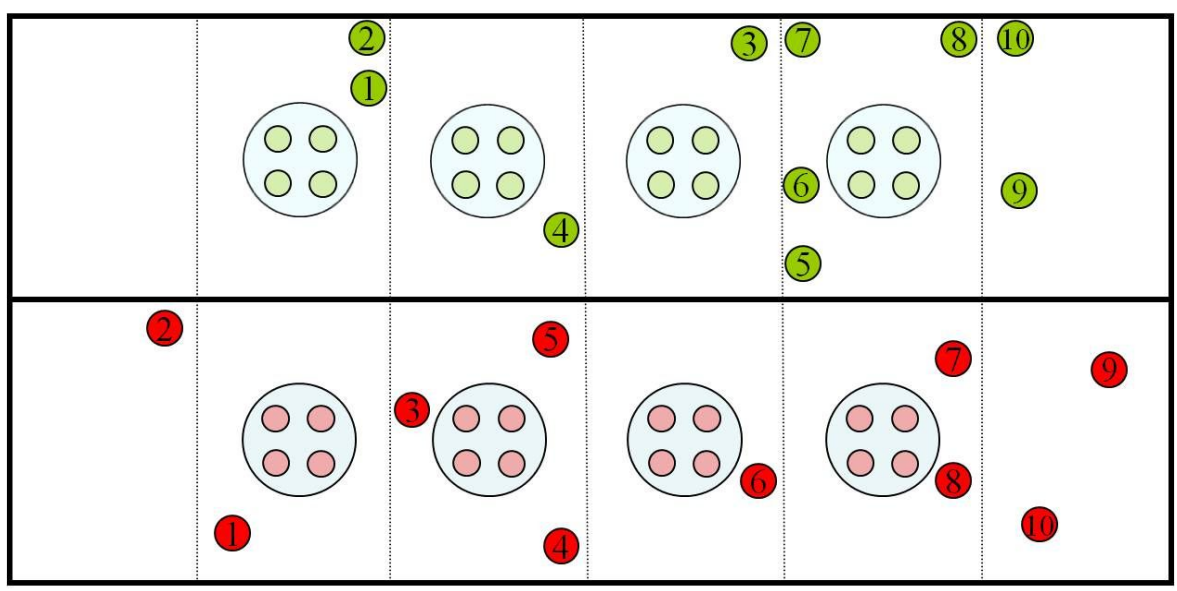

Fig. 1 - Schematic drawing of the experimental site. Lysimeters are represented by light blue circles. Green and red circles represent beech saplings fumigated with respectively ambient and twice ambient ozone. Numbered circles show the position of the used beech saplings in the experiment. ozone was fumigated from May (before bud break) until end of October (after leaf senescence). During the last experimental year saplings were fumigated from May until end of August. Ozone fumigation was restricted to concentrations lower than $150 \mathrm{nl} \mathrm{l}^{-1}$, in order to avoid acute injury of leaves. During the harvesting year of 2006 the ozone concentration resulted in an AOT 40 value of $52.6 \mathrm{\mu l} \mathrm{l}^{-1} \mathrm{~h}$. Details about the ozone concentration are given by Winkler et al. (2009). Ten trees from the lysimeter around area were used as biological replicates for each group category (ambient and twice ambient ozone defined respectively as control and treatment group - Fig. 1). From each tree, three sun exposed crown leaves were taken on $27^{\text {th }}$ of July 2006 . Leaves from one tree were combined and immediately frozen in liquid nitrogen. At the harvesting time point, beech saplings were seven years old. Fig. 2 gives an overview of the experimental setup.

\section{Protein extraction}

Each biological sample consisted of a pool of three leaves from one tree. Samples were ground to a fine powder using a micro dismembrator (BRAUN ${ }^{\mathrm{TM}}$ ) without interruption of the cooling chain. Soluble proteins were extracted using $100 \mathrm{mg}$ of fresh weight material according to the protocol of Vâlcu \& Schlink (2006) with some modifications. In brief, proteins were precipitated over night at $-20^{\circ} \mathrm{C}$ in $10 \%$ TCA, $1 \%$ polyvinyl polypyrrolidone (PVPP), 0.07\% 2-mercaptoethanol in ice cold acetone (Damerval et al. 1986). Pellet was centrifuged at $26000 \times \mathrm{g}$ for 30 min at $4{ }^{\circ} \mathrm{C}$. Supernatant was removed and the remaining pellet was washed in ice cold acetone with $0.07 \%$ 2-mercaptoethanol for one hour at $-20^{\circ} \mathrm{C}$. The washing procedure was repeated once. Finally the pellet was centrifuged $\left(26000 \mathrm{x} \mathrm{g}, 30 \mathrm{~min}, 4^{\circ} \mathrm{C}\right)$, dried for $1 \mathrm{~h}$ on ice, resuspended in $1 \mathrm{ml}$ extraction buffer ( $7 \mathrm{M}$ urea, $2 \mathrm{M}$ thiourea, $2 \%$ Octyl- $\beta$ -

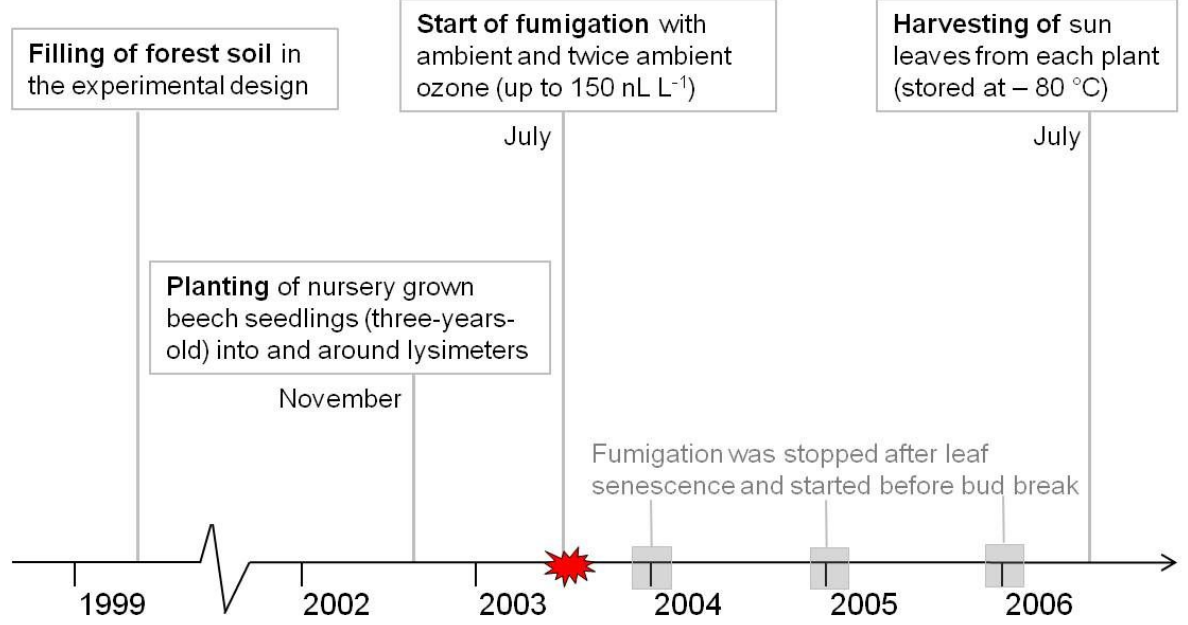

Fig. 2 - Schematic diagram of the experimental design in the time scale. Proteomic analyses were performed for the time point $27^{\text {th }}$ July 2006. 
D-glucopyranoside, $40 \mathrm{mM}$ TRIS) and sonicated for $30 \mathrm{~min}$ in a water-bath sonicator, at 4- $7{ }^{\circ} \mathrm{C}$. The extract was centrifuged at $4{ }^{\circ} \mathrm{C}$ and the $\mathrm{pH}$ was adjusted to 8.5 using 100 $\mathrm{mM} \mathrm{NaOH}$. Total protein amount from each sample was measured based on a modified Lowry test using the RC-DC ${ }^{\mathrm{TM}}$ Protein Assay kit $\mathrm{BIORAD}^{\mathrm{TM}}$ and $\mathrm{BSA}$ as standard to generate a regression line.

\section{Two-dimensional gel electrophoresis}

Prior separation $50 \mu \mathrm{g}$ of each sample and internal standard were labeled with $200 \mathrm{pmol}$ of CyDyes diluted in N,N-dimethylformamide. A randomized sample labeling with Cy3 and Cy5 dyes was used in order to avoid systemic errors introduced during the labeling reaction. Cy2 was used to label the internal standard that consisted of equal amounts of all protein extracts from control and treatment samples within the experiment. A total of ten 2-D gels, each consisting of an internal standard, a control and a treatment sample, were used to separate proteins For the isoelectric focusing (IEF), $24 \mathrm{~cm}$ and $18 \mathrm{~cm}$ strips were used with a linear $\mathrm{pI}$ gradient ranging from 4-7 and 6-11 (GE Healthcare). CyDyes labelled samples (a total of $150 \mu \mathrm{g}$ ) were mixed in rehydration solution (7 M urea, $2 \mathrm{M}$ thiourea, $2 \mathrm{mM}$ 2-hydroxyethyl disulfide, $2 \%$ Octyl- $\beta$-D-glucopyranoside, $0.5 \%$ Pharmalyte $3-10,0.002 \%$ bromophenol blue and further $10 \%$ isopropanol for basic gradients) and loaded onto IPG DryStrips using in-gel sample rehydration technique for gels with $\mathrm{pI}$ 4-7. Proteins separated in gels pI 6-11 were cup loaded prior to IEF. After rehydration for 12 hours IEF was carried out with a maximum current setting of $50 \mathrm{~mA} /$ strip at $20{ }^{\circ} \mathrm{C}$ on an Ettan IPGphor Manifold (GE Healthcare). The system was programmed for strips $\mathrm{pI}$ 4-7 as follows: $150 \mathrm{~V}$ for $6 \mathrm{~h}, 150-300 \mathrm{~V}$ for $4 \mathrm{~h}$, $300-1000 \mathrm{~V}$ for $11.25 \mathrm{~h}, 1000-8000 \mathrm{~V}$ for 3 $\mathrm{h}$ and $8000 \mathrm{~V}$ for $5 \mathrm{~h}$. For strips pI 6-11 following settings were used: $150 \mathrm{~V}$ for $5 \mathrm{~h}$, $300 \mathrm{~V}$ for $3 \mathrm{~h}, 300-1000 \mathrm{~V}$ for $6 \mathrm{~h}, 1000$ $8000 \mathrm{~V}$ for $3 \mathrm{~h}$ and $8000 \mathrm{~V}$ for $1.5 \mathrm{~h}$. After IEF each strip was equilibrated with $10 \mathrm{~mL}$ of equilibration solution (6 M urea, $75 \mathrm{mM}$ Tris- $\mathrm{HCl} \mathrm{pH} 8.8,30 \%$ glycerol, $2 \%$ SDS, $0.002 \%$ bromophenol blue). Equilibration was performed in two steps each $15 \mathrm{~min}$, with $1 \% \mathrm{w} / \mathrm{v}$ dithiothreitol in the first equilibration, and $2.5 \% \mathrm{w} / \mathrm{v}$ iodoacetamide in the second equilibration. SDS-PAGE was carried out on an Ettan DALT six system (GE Healthcare) in $12.5 \%$, 1-mm-thick polyacrylamide gels. Electrophoretical conditions were applied as follows: $30 \mathrm{~mA}$ for $1 \mathrm{~h}, 48$ $\mathrm{mA}$ for $1 \mathrm{~h}$ and $98 \mathrm{~mA}$ over night.

\section{Protein visualization}

Gels were scanned using a Typhoon 9410 imager (GE Healthcare) at $100 \mu \mathrm{m}$ resolution. $\mathrm{Cy} 2, \mathrm{Cy} 3$ and $\mathrm{Cy} 5$ dyes were respec- tively excited at 488, 532 and $633 \mathrm{~nm}$.

Raw gel images were aligned with PROGeNESIS SAMESPots ${ }^{\circledR}$ software (Nonlinear Dynamics) using a master gel as reference. Virtually wrapped gels were imported in $\mathrm{DECYDER}^{\circledR} 6.5$ software (GE Healthcare) for further 2-DE spot identification, normalization and quantification.

\section{Statistical analysis}

The low separation and labeling quality of proteins from gel 7 resulted in the exclusion of samples from tree number 7 of both groups. A total of 27 gel images ( 9 controls, 9 treated and 9 internal standards) were used for statistical analysis. The abundance of each protein was estimated by the volumes (sum of pixel intensity within the spot boundary). Differences in spot intensity between groups were compared using the Student's $t$-test function implemented into DeCyder. Based on the $p$ values, $q$ values were calculated according to Benjamini \& Hochberg (2000) in order to rejected false positives. Only protein abundances showing significances lower than $(\mathrm{q} \leq 0.05)$ and an absolute ratio of at least 1.3 fold were used for protein identification.

\section{Protein digestion and identification by liquid chromatographic-tandem mass spectrometry (LC MS/MS)}

Preparative gels loading 700-800 $\mu$ g total protein amount were run and stained with colloidal Coomassie G-250 (CBB) according to Candiano et al. (2004). Low abundant protein spots were visualized using 150-250 $\mu \mathrm{g}$ total protein amount and silver stained with a MS compatible method (Heukeshoven \& Dernick 1988), without using formaldehyde and glutaraldehyde in the sensitizing and silver solution, respectively). Selected spots were manually excised using a scalpel. CBB extracted spots were then destained in $40 \%$ ethanol/50 $\mathrm{mM}$ ammonium bicarbonate ultra pure. Silver stained spots were destained in a $2 \%$ potassium hexacyanoferrate $/ 3.2 \%$ sodium thiosulphate 1:1 mixture and washed five times with water. Spots were dehydrated with acetonitrile (ACN) and dried in a vacuum centrifuge. Gel pieces were rehydrated in $10 \mathrm{ng} / \mu \mathrm{L}$ trypsin solution (Sigma-Aldrich) in $50 \mathrm{mM}$ ammonium bicarbonate and incubated over night at $37^{\circ} \mathrm{C}$. Hydrophilic peptides were extracted with $40 \mathrm{mM}$ ammonium bicarbonate $10 \% \mathrm{ACN}$ at room temperature for $10 \mathrm{~min}$. Hydrophobic peptides were extracted with $47 \% \mathrm{v} / \mathrm{v}$ ACN, $5 \% \mathrm{v} / \mathrm{v}$ formic acid and the extraction step was repeated twice. All three supernatants were pooled together, concentrated in a vacuum centrifuge, acidified with formic acid and stored at -20 ${ }^{\circ} \mathrm{C}$.

Peptide mixtures were analyzed by on-line capillary nano HPLC (LC Packings, Amsterdam, Netherlands) coupled to a nanospray
LCQ Deca XP ion trap mass spectrometer (ThermoFinnigan, San Jose, CA, USA). Peptide digest $(10 \mu \mathrm{L})$ were loaded onto $300 \mu \mathrm{m}$ inner diameter x $5 \mathrm{~mm} \mathrm{C18}$ PepMAP $^{\mathrm{TM}}$ trap column (LC Packings, Amsterdam, Netherlands) at a flow rate of $30 \mu 1 / \mathrm{min}$. The peptides were eluted from the trap column onto an analytical $75 \mu \mathrm{m}$ inner diameter x $15 \mathrm{~cm}$ C18 PEPMAP ${ }^{\mathrm{TM}}$ column (LC Packings, Amsterdam, Netherlands) with a $5-40 \%$ linear gradient of solvent $\mathrm{B}$ in $30 \mathrm{~min}$ (solvent $\mathrm{A}$ was $0.1 \%$ formic acid in $5 \% \mathrm{ACN}$, and solvent B was $0.1 \%$ formic acid in $80 \%$ ACN). The separation flow rate was set at $200 \mathrm{nl} / \mathrm{min}$. The mass spectrometer operated in positive ion mode at a $1.8 \mathrm{kV}$ needle voltage and a $28 \mathrm{~V}$ capillary voltage. Data acquisition was performed in a data-dependent mode by alternating a MS scan survey over the range $\mathrm{m} / \mathrm{z} \quad 300-1700$ and three MS/MS scans in an exclusion dynamic mode. MS/MS spectra were acquired using a $2 \mathrm{~m} / \mathrm{z}$ units ion isolation window at $35 \%$ relative collision energy and $0.5 \mathrm{~min}$ dynamic exclusion duration. Peptides were identified with SEQUESTTM algorithm through BIOWORKS 3.3.1 interface (Thermo-Finnigan, Torrence, CA, USA) against a Fagus contigs consensus database (293388 entries from http://www.evoltree.com) translated in 6 reading frames by TRANSEQ software (http:// www.cbib.u-bordeaux 2.fr/pise/transeq.html). The generation of mass spectra data in SE-

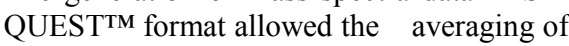
several MS/MS spectra corresponding to the same precursor ion with a tolerance of 1.4 Da. Spectra from precursor ion higher than $3500 \mathrm{Da}$ or lower than $600 \mathrm{Da}$ were rejected. The search parameters were as follows: mass accuracy of the peptide precursor and peptide fragments was set to 2 and $1 \mathrm{Da}$, respectively. Only b- and y-ions were considered for mass calculation. Oxidation of methionines $(+16 \mathrm{Da})$ and carbamidomethylation of cysteines $(+57 \mathrm{Da})$ were considered as differential modifications. Two missed trypsin cleavages were allowed. Tryptic peptides were validated using the following criteria (DeltaCN $\geq 0.1$, Xcorr $\geq 1.9$ (single charge), 2.2 (double charge), 3.75 (triple charge), 3.0 (quadruple charge), peptide probability $\leq$ 0.001 . EST annotations were identified by searching with a protein Viridiplantae index from Swiss-Prot (BLASTX) and TrEMBL (BLASTX) database using UniProtKB (http://www.uniprot.org).

\section{Results and discussion}

In the present study we analyzed ozone-related responses of European beech leaves following four vegetation periods of ozone fumigation under field conditions. Visible foliar symptoms represented by leaf discoloured areas were recorded for five time points on beech saplings grown inside lysimeters $(\mathrm{n}=16$ trees/group - Grams, pers. 


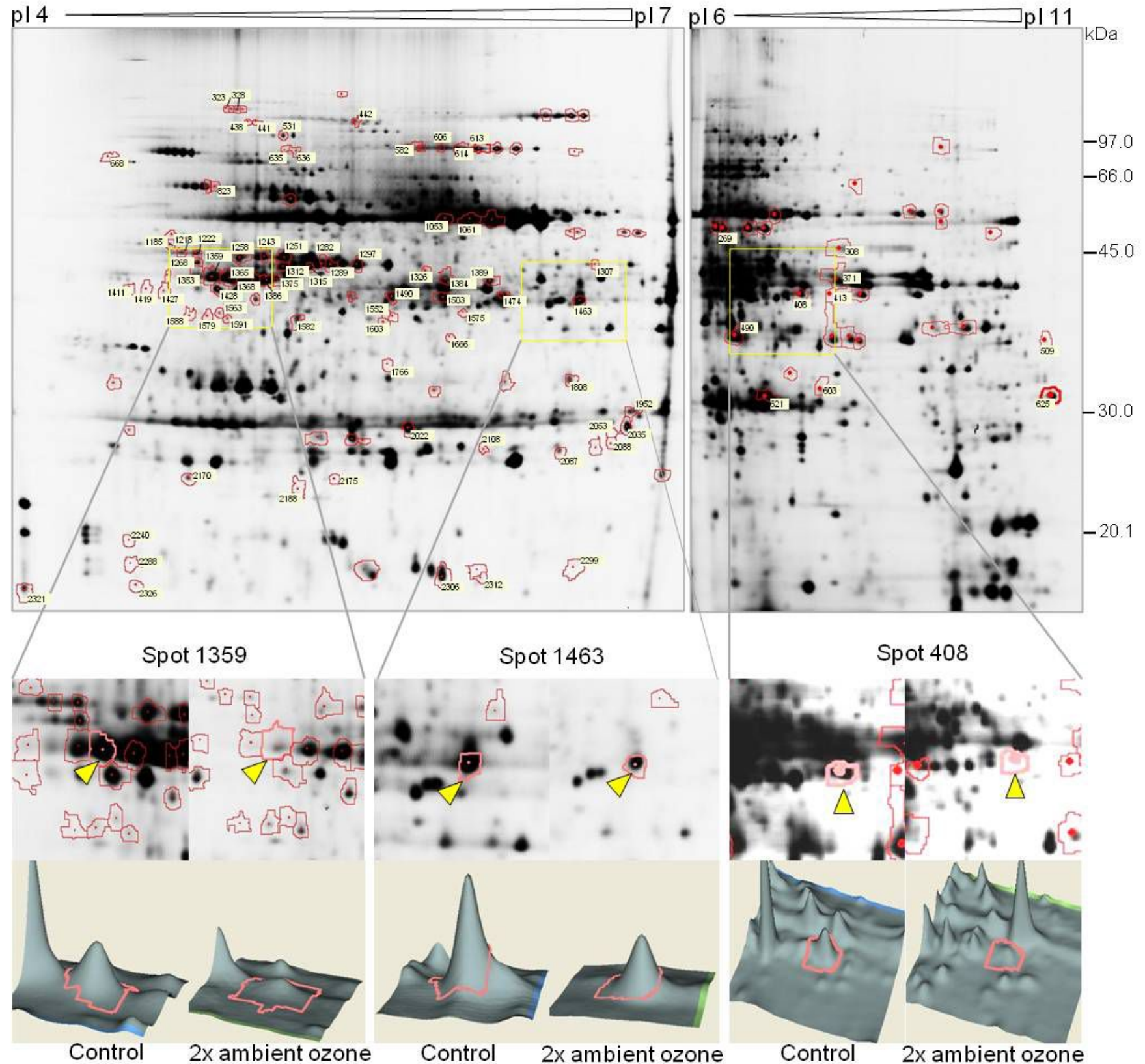

Fig. 3 - DIGE labelled 2-D gels of separated soluble proteins from European beech leaves. Red marked protein spots indicate changes in their regulation after statistical analysis. Zoomed squares exemplify patterns of protein regulation. Spots labeled with triangles area visualized as 3-D graph in the area below.

comm.). Results did not show any visually symptom on foliar injury following ozone exposure for the harvesting time point of the proteomic approach $\left(27^{\text {th }}\right.$ of July).

\section{Ozone responsive proteins detected by \\ 2-D DIGE}

After image analysis of 2-D gels we could observe on average a total amount of 1350 spots in both pI ranges (pI 4-7 and pI 6-11). Our results showed that $9 \%$ of the total protein spots were differentially regulated on abundance after elevated ozone fumigation The image analysis revealed that in the $\mathrm{pI}$ range 4-7, 114 spots and in the pI range 611,28 spots showed different protein abundances by comparing samples fumigated with twice ambient ozone versus the control treatment (Fig. 3). From the total of 142 spots showing a significant different spot volume, 88 spots could be visualized in agreement with the preparative silver stained gels. As a first step, 46 protein spots were subjected to mass spectrometry identification (LC-MS/ MS) followed by a homology driven search. The mass spectra of 6 spots failed to show any peak while 27 spots resulted in multiple protein mixtures. As for the remaining 13 spots, proteins were identified (Tab. 1), which are particularly involved in the Calvin cycle, photosynthetic electron transport chain and carbon metabolism/catabolism.

Ozone exposure affects proteins related to the Calvin cycle and the photosynthetic electron transport chain The highest number of altered proteins according to a single metabolic pathway was observed in the Calvin cycle, where a total of seven chloroplast proteins were reduced in amount. The enzyme probable ribulose-1.5bisphosphate carboxylase/oxygenase (Ru- 
Tab. 1 - List of identified proteins by LC-MS/MS. (a) Number of protein spot on the 2-D gel; (b) Accession number from the best homologous protein in Swiss-Prot and/or TrEMBL database; (c) Q-value calculated by treatment interaction of control versus treated samples. Values were calculated based on of the Student's $t$-test after applying a false discovery rate according to Benjamini \& Hochberg (2000); (d) Average ratio calculated from the normalized protein volumes. Negative values are given as negative reciprocal value (average ratio=-1/aver age); (e) Normalized average spot volumes (sum of pixel intensity within the spot boundary) for control (CONT) and treated (TREAT) groups; (f) Standard deviation from protein spot volumes of the controls (Cont) and treated (TReAT) samples; (g) Experimental Mw (in Da) and pI. Data were estimated in comparison to a 2-D gel with marker proteins; (h) Theoretical Mw (in $\mathrm{kDa}$ ) computed by the expasy website (http://us.expasy.org/tools/peptide-mass.html); (i) Number of matching peptides. See Supplementary Material for peptides sequence; (j) Ratio of the amino acids in detected peptides to total protein amino acids: coverage. Values are given in \%; (k) Location of identified proteins: chloroplast (chloropl.), mitochondrion (mitoch.), plasma membrane (pl. memb.).

\begin{tabular}{|c|c|c|c|c|c|c|c|c|c|c|c|c|c|c|c|}
\hline \multirow[t]{2}{*}{$\begin{array}{l}\text { Spot } \\
\text { no }\end{array}$} & \multirow[t]{2}{*}{$\begin{array}{l}\text { Accession } \\
\text { number }\end{array}$} & \multirow[t]{2}{*}{$\begin{array}{c}\text { Identified } \\
\text { protein }\end{array}$} & \multirow[t]{2}{*}{$\begin{array}{c}\text { Q- } \\
\text { value }^{(\mathrm{c})}\end{array}$} & \multirow[t]{2}{*}{$\begin{array}{l}\text { Average } \\
\text { ratio }^{(\mathrm{d})}\end{array}$} & \multicolumn{2}{|c|}{ Volume $^{(\mathrm{e})}$} & \multicolumn{2}{|c|}{$\begin{array}{c}\text { Standard } \\
\text { deviation }^{(\mathfrak{f})}\end{array}$} & \multicolumn{2}{|c|}{ Exp. ${ }^{(g)}$} & \multicolumn{2}{|c|}{ Theo. $^{(\mathrm{h})}$} & \multicolumn{2}{|c|}{$\begin{array}{c}\text { Data from the } \\
\text { SEQUEST } \\
\text { search }\end{array}$} & \multirow{2}{*}{ Compart. $^{(\mathrm{k})}$} \\
\hline & & & & & Cont & Treat & Cont & Treat & pI & Mw & pI & Mw & $\mathbf{M}^{(\mathbf{i})}$ & Cov. $^{(j)}$ & \\
\hline \multicolumn{16}{|c|}{ Calvin Cycle photosynthesis related proteins } \\
\hline 613 & Q43848 & Transketolase & 0.0054 & $\downarrow-2.13$ & 13.1 & 6.16 & 5.64 & 3.24 & 6.16 & 88 & 5.53 & 72.93 & 3 & 3.97 & \\
\hline 1389 & Q42961 & Phosphoglycerate kinase & 0.0040 & 09 & 9.02 & 4.21 & 3.37 & 2.14 & 6.19 & 55 & 5.59 & 42.58 & 2 & 7.58 & \\
\hline 1353 & Q40281 & RuBisCO activase & 0.0024 & $\downarrow-1.89$ & 11.75 & 6.27 & 5.04 & 2.78 & 5.08 & 56 & 8.2 & 48.07 & 3 & 8.49 & chloropl. \\
\hline 408 & Q9ZU52 & $\begin{array}{l}\text { Probable frutctose- } \\
\text { bisphosphate aldolase } 3\end{array}$ & 0.0091 & $\downarrow-1.81$ & 67.51 & 36.36 & 2.96 & 1.56 & 7.12 & 40 & 6.08 & 38.08 & 4 & 10.75 & ropl. \\
\hline 621 & P27141 & Carbonic anhydrase & 0.0043 & & 215.32 & 154.59 & & 4.88 & 6.79 & 28 & 6.19 & 23.96 & 1 & 3.6 & \\
\hline 1463 & P16096 & $\begin{array}{l}\text { Fructose-bisphosphate } \\
\text { aldolase }\end{array}$ & 0.0001 & $\downarrow-1.55$ & 27.49 & 17.6 & 7.65 & 4.5 & 6.51 & 53 & 5.8 & 37.7 & 4 & 7.19 & \\
\hline 1428 & P46283 & $\begin{array}{l}\text { Sedoheptulose-1.7 } \\
\text { bisphosphatase }\end{array}$ & 0.0077 & $\downarrow-1.55$ & 12.27 & 7.72 & 3.49 & 1.67 & 5.16 & 53 & 6.17 & 42.41 & 3 & 10.86 & chloropl. \\
\hline 1386 & P27774 & Phosphoribulokinase & 0.0021 & $\downarrow-1.53$ & 29.72 & 18.74 & 13.99 & 8.43 & 5.33 & 55 & 5.22 & 39.18 & 5 & 10.7 & chloropl. \\
\hline 490 & Q9ZUC1 & $\begin{array}{l}\text { Quinone oxidoreductase- } \\
\text { like protein Atlg23740 }\end{array}$ & 0.0012 & $\downarrow-1.64$ & 181.16 & 113.29 & 6.12 & 5.39 & 6.49 & 35 & 8.46 & 40.98 & 7 & 22.4 & chloropl. \\
\hline \multicolumn{16}{|c|}{ Carbon metabolism/catabolism } \\
\hline 1563 & Q9SIDO & Probable fructokinase-1 & & $\uparrow 1.32$ & 1.04 & 1.38 & 0.39 & 0.22 & 5.17 & 49 & 5.31 & 35.28 & 2 & 4. & \\
\hline 2326 & P80499 & $\begin{array}{l}\text { Cytochrome c oxidase } \\
\text { subunit } 5 \mathrm{~B}\end{array}$ & 0.0011 & $\uparrow 1.7$ & 1.72 & 2.93 & 0.29 & 0.74 & 4.88 & 18 & 4.96 & 3.1 & 3 & 6.13 & \\
\hline 2288 & P80499 & $\begin{array}{l}\text { Cytochrome c oxidase } \\
\text { subunit } 5 \mathrm{~B}\end{array}$ & 0.0006 & $\uparrow 5.19$ & 0.64 & 3.47 & 0.47 & 1.92 & 4.87 & 20 & 4.96 & 3.1 & 1 & 3.68 & mitoch. \\
\hline 2188 & Q9FT52 & ATP synthase subunit $d$ & 0.0040 & $\uparrow 1.77$ & 1.39 & 2.4 & & 0.66 & 5.46 & 26 & 5.09 & 19.45 & 2 & 3.8 & mitoch. \\
\hline
\end{tabular}

BisCO) activase (spot 1353) and carbonic anhydrase (spot 621), two enzymes involved in the carboxylation process by regulating the activity of RuBisCO, showed respectively decreased abundance ratios of -1.89 and -1.61 fold compared to the controls. Also the reduction part of the Calvin cycle was affected by decreased abundance levels of phosphoglycerate kinase (spot 1389). Furthermore, phosphoribulokinase (spot 1386), sedoheptulose-1.7-bisphosphatase (spot 1428), two isoforms of probable fructose-bisphosphate aldolase (spot 408/1463) and transketolase (spot 613), enzymes implicated in the regeneration of ribulose-1.5-bisphosphat, were also reduced in their amount. Similar results were observed in other plant species treated with short-term ozone exposure (Cho et al. 2008, Feng et al. 2008, Ahsan et al. 2010). In rice seedlings a considerably reduction of both, the large and the small subunit of $\mathrm{RuBisCO}$ was shown at the protein level (Agrawal et al. 2002). Nearly the same results as in this report were found after a short-time period of elevated ozone exposure in poplar, where different proteins regarding the Calvin cycle were reduced in amount
(Bohler et al. 2007). From this fact it can be deduced that reduced carboxylation may be a general reaction of plants after short- as well as long-time periods of ozone exposure. Although in the present study there was no indication that the amount of RuBisCO present in the leaves was affected after treatment, ozone may directly or indirectly reduce the amount of RuBisCO activase and carbonic anhydrase. As a consequence of decreased $\mathrm{CO}_{2}$ fixation, less enzyme intermediates in the Calvin cycle are needed to process the substrate.

The Calvin cycle activity has been suggested to be a major sink of ATP and nicotinamide adenine dinucleotide phosphate produced during photosynthesis (Lawson et al. 2002). Thus, an overall decrease in the activity of the Calvin cycle upon ozone exposure would release an accumulation of both photosynthetic products. In order to prevent photooxidative damage, plants may reduce the electron transport chain of photosynthesis (Ranieri et al. 2001, Bohler et al. 2007). Our results support this hypothesis since the enzyme quinone oxidoreductase-like protein (spot 490) responsible for reducing quinone, showed decreased levels. Elevated ozone also decreased gene expression levels of quinone oxidoreductase-like protein in two silver birch genotypes following two growing seasons of ozone exposure (Kontunen-Soppela et al. 2010). Furthermore, our finding is in accordance with previous reported transcript analysis from the same plant material which revealed a down-regulation of ESTs related to photosynthesis such as chloroplast envelope quinone-oxidoreductase of electron transport, chlorophyll a/b-binding protein, thioredoxin M-type, glycolate oxidase a and nuclear-encoded chloroplast ribulose-5-phosphate-3-epimerase thioredoxin on the $27^{\text {th }}$ of July 2006 (Olbrich et al. 2009).

An ozone related down-regulation of enzymes associated with the Calvin cycle suggest that less triose-phosphates are produced during the $\mathrm{CO}_{2}$ fixation process, thus leading to a decreased availability of substrates for energy production (Bohler et al. 2007). Initially most triose-phosphates are used in the synthesis of starch and sucrose, the primary photosynthetic products and the most important energy source in plants. Our results indicating a general down-regulation of the 


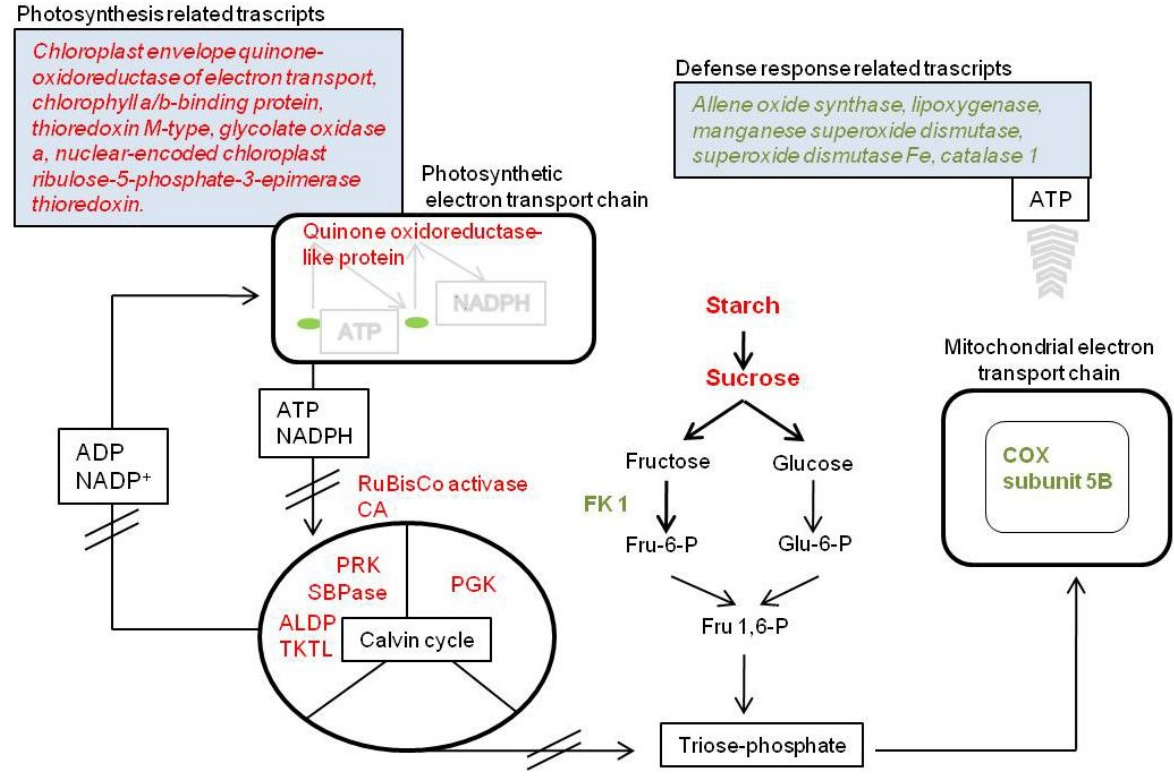

Fig. 4 - Illustration of possible molecular changes in beech leaves exposed to elevated ozone. Red and green colored transcripts/proteins/metabolites were respectively decreased/increased in amount. Transcripts are shown in italics, whereas metabolites in bold. (CA): carbonic anhydrase; (RuBisCO activase): ribulose-1.5-bisphosphat-carboxylase/-oxygenase activase; (PGK): phosphoglycerate kinase; (PRK): phosphoribulokinase; (SBPase): sedoheptulose1.7-bisphosphatase; (ALDP): fructose-bisphosphate aldolase; (TKTL): transketolase; (COX subunit 5B): cytochrome c oxidase subunit 5B; (Fru-6-P): fructose 6-phosphate; (Glu-6-P): glucose 6-phosphate; (ATP): Adenosine-5'-triphosphate; (ADP): adenosine diphosphate; (NADPH): reduced nicotinamide adenine dinucleotide phosphate; $\left(\mathrm{NADP}^{+}\right)$: nicotinamide adenine dinucleotide phosphate (FK 1): probable fructokinase-1.

Calvin cycle and its product triose-phosphate are in agreement with the reduced levels of sucrose concentrations in leaves exposed to elevated ozone fumigation at any time point of this experiment; also on the $26^{\text {th }}$ of July 2006 (Fleischman et al. 2009). Similar results were reported in juvenile as well as mature beech leaves exposed to elevated ozone (Liu et al. 2004, Blumenröther et al. 2007).

\section{Ozone induced an accumulation of proteins regarding carbon metabolism/catabolism and} mitochondrial electron transport chain

In contrast to the Calvin cycle and the photosynthetic apparatus three proteins regarding the carbon metabolism/catabolism showed increased amounts in elevated ozone exposed beech leaves. There is strong evidence that catabolic pathways (e.g., glycolysis, hexose monophosphate pathway, tricarboxylic acid (TCA) cycle and the mitochondrial electron transport system) are up-regulated upon ozone exposure in order to maintain the energy and the reducing power needed to detoxify and repair cellular damage caused by reactive oxygen species (Dizengremel 2001, Bohler et al. 2007, Dizengremel et al. 2009, Ahsan et al. 2010). Responses against cellular damage were observed in the present study. For the time point $27^{\text {th }}$ of July 2006 , transcript levels of allene oxide synthase, lipoxygenase, manganese superoxide dismutase, superoxide dismutase $\mathrm{Fe}$ and catalase 1 were observed to be increased (Olbrich et al. 2009). At the proteome level we could identify increased amounts of the enzyme probable fructokinase 1 (spot 1563), a phosphotransferase involved in carbon metabolism/catabolism used for respiration and biosynthesis of starch and other complex carbohydrates (Odanaka et al. 2002). Based on these results, the reduced levels of starch and sucrose inticated in this experiment (Fleischmann et al. 2009) as well as previous evidences that catabolic pathways are increased upon ozone, we support the hypothesis that the carbon metabolism/catabolism is impaired during ozone stress (Ahsan et al. 2010). Thus, starch is converted to sucrose which is then degraded by the increased carbon catabolism in order to feed the TCA cycle (Fig. 4).

Further two proteins which are embedded in the mitochondrial electron transport chain, cytochrome c oxidase subunit 5B (spot 2326/2288) and ATP synthase subunit D (spot 2188), were more abundant in treated leaves. In Scots pine needles ozone led to increased enzymatic activities of cytochrome oxidase (Luethy-Krause et al. 1990). Furthermore, ozone increased mitochondrial respiration rates of aspen clones (Coleman et al. 1995), hybrid polar (Reich 1983) and ginkgo biloba (He et al. 2007). Cytochrome c oxidase and ATP synthase are mitochondrial enzymes needed for generating an electrochemical potential and production of ATP. Consequently higher amounts of both molecules may indicate an increased respiration. In leaves increased respiration intensity has frequently observed to be linked with simultaneous reduction in photosynthesis (Roshchina \& Roshchina 2003). Furthermore, higher respiration intensity has been suggested to be a response of defense and repair mechanism in ozone damaged tissues (Bahl et al. 1993). Our results showing increased amounts of two essential proteins for the ATP production support the hypothesis of an increased mitochondrial respiration.

\section{Concluding remarks}

Although our proteome profile represents only a snap-shot of chronic ozone effects in plants grown under field conditions, it confirmed previous reported short-term ozone effects on plant species including poplar, rice and soybean. In general $\mathrm{CO}_{2}$ fixation is reduced showing decreased amounts in proteins related to the Calvin cycle. These results are accompanied by reduced amounts of photosynthetic proteins/transcripts and an overall increase in proteins involved in metabolic/catabolic pathways.

In the present work proteomic analyses, indicated complementary responses to previous reported transcript analysis from the same experiment (Olbrich et al. 2009) as well as sucrose and starch results of leaves from lysimeter grown beech saplings. Our comprehensive protein analysis will be continued by extending time points and linking analytical data in order to better understand ozone-related effects under a more realistically ecological environment.

\section{Acknowledgements}

We are grateful to Christophe Plomion and Stephane Claverol for very helpful comments and substantial organizational support concerning the LC-MS/MS analyses. The authors would also like to thank Sarah Sturm for excellent technical assistance and Edgar Delgado-Eckert for critical reading the manuscript. This research was carried out with financial support from the Deutsche Forschungsgemeinschaft (SFB 607) and, with respect to LC-MS/MS, by the Biodiversité Gènes et Communautés, INRA within the frame of the Network of Excellence "EVOLTREE".

\section{References}

Agrawal GK, Rakwal R, Yonekura M, Kubo A Saji H (2002). Proteome analysis of differentially displayed proteins as a tool for investigating ozone stress in rice (Oryza sativa L.) seedlings. Proteomics 2: 947-959. - doi: 10.1002/1615- 
9861(200208)2:8<947::AID-PROT947>3.0.CO; 2-J

Ahsan N, Nanjo Y, Sawada H, Kohno Y, Komatsu S (2010). Ozone stress-induced proteomic changes in leaf total soluble and chloroplast proteins of soybean reveal that carbon allocation is involved in adaptation in the early developmental stage. Proteomics 10: 2605-2619. - doi: 10.1002/pmic. 201000180

Bahl A, Loitsch SM, Kahl G (1993). Air pollution and plant gene expression. Plant responses to the environment. P. M. Gresshoff. Knoxville, Tennessee, USA, pp. 184.

Benjamini Y, Hochberg Y (2000). On the adaptive control of the false discovery rate in multiple testing with independent statistics. Journal of Educational and Behavioral Statistics 25: 60-83. - doi: 10.3102/10769986025001060

Blumenröther MC, Löw M, Matyssek R, Oßwald W (2007). Flux-based response of sucrose and starch in leaves of adult beech trees (Fagus sylvatica L.) under chronic free-air $\mathrm{O}_{3}$ fumigation. Plant Biology 9: 207-214. - doi: 10.1055/s2006-924565

Bohler S, Bagard, Mouhssin Oufir M, Planchon S, Hoffmann L, Jean-François YJ, Dizengremel HP, Renaut J (2007). A DIGE analysis of developing poplar leaves subjected to ozone reveals major changes in carbon metabolism. Proteomics 7: 1584-1599. - doi: 10.1002/pmic.200600822

Candiano G, Bruschi M, Musante L, Santucci L, Ghiggeri GM, Carnemolla B, Orecchia P, Zardi L, Righetti PG (2004). Blue silver: a very sensitive colloidal Coomassie G-250 staining for proteome analysis. Electrophoresis 25: 1327-1333. doi: 10.1002/elps.200305844

Cho K, Shibato J, Agrawal GK, Jung Y-H, Kubo A, Jwa N-S, Tamogami S, Satoh K, Kikuchi S, Higashi T, Kimura S, Saji H, Tanaka Y, Iwahashi H, Masuo Y, Rakwal R (2008). Integrated transcriptomics, proteomics, and metabolomics analyses to survey ozone responses in the leaves of rice seedling. Journal of Proteome Research 7: 2980-2998. - doi: 10.1021/pr800128q

Coleman MD, Isebrands JG, Dickson RE, Karnosky DF (1995). Photosynthetic productivity of aspen clones varying in sensitivity to tropospheric ozone. Tree Physiology 15: 585-592. doi: 10.1093/treephys/15.9.585

Damerval C, De Vienne D, Zivy M, Thiellement $H$ (1986). Technical improvements in two-dimensional electrophoresis increase the level of genetic variation detected in wheat-seedling proteins. Electrophoresis 7: 52-54. - doi: 10.1002/ elps. 1150070108

Dizengremel P (2001). Effects of ozone on the carbon metabolism of forest trees. Plant Physiology and Biochemistry 39: 729-742. - doi: 10.1016/S0981-9428(01)01291-8

Dizengremel P, Thiec DL, Hasenfratz-Sauder MP, Vaultier MN, Bagard M, Jolivet Y (2009). Metabolic-dependent changes in plant cell redox power after ozone exposure. Plant Biology 11: 35-42. - doi: 10.1111/j.1438-8677.2009.00261.x

Feng Y, Komatsu S, Furukawa T, Koshiba T, Kohno Y (2008). Proteome analysis of proteins responsive to ambient and elevated ozone in rice seedlings. Agriculture, Ecosystems \& Environment 125: 255-265. - doi: 10.1016/j.agee.2008. 01.018

Fleischman F, Winkler JB, Oßwald W (2009). Effects of ozone and Phytophthora citricola on non-structural carbohydrates of European beech (Fagus sylvatica) saplings. Plant Soil 323: 75-84. - doi: 10.1007/ s11104-009-9927-y

He XY, Fu SL, Chen W, Zhao TH, Xu S, Tuba Z (2007). Changes in effects of ozone exposure on growth, photosynthesis, and respiration of Ginkgo biloba in Shenyang urban area. Photosynthetica 45: 555-561. - doi: 10.1007/s11099007-0095-0

Heukeshoven J, Dernick R (1988). Improved silver staining procedure for fast staining in PhastSystem Development Unit. I. Staining of sodium dodecyl sulfate gels. Electrophoresis 9: 28-32. doi: 10.1002/elps. 1150090106

Hough AM, Derwent RG (1990). Changes in the global concentration of tropospheric ozone due to human activities. Nature 344: 645-648. - doi: $10.1038 / 344645 \mathrm{a} 0$

Jorrín-Novo JV, Maldonado AM, Echevarría-Zomeño S, Valledor L, Castillejo MA, Curto M, Valero J, Sghaier B, Donoso G, Redondo I (2009). Plant proteomics update (2007-2008): Second-generation proteomic techniques, an appropriate experimental design, and data analysis to fulfill MIAPE standards, increase plant proteome coverage and expand biological knowledge. Journal of Proteomics 72: 285-314. - doi: 10.1016/j.jprot.2009.01.026

Kontunen-Soppela S, Riikonen J, Ruhanen H, Brosché M, Somervuo P, Peltonen P, Kangasjärvi J, Auvinen P, Paulin L, Keinänen M, Oksanen E, Vapaavuori E (2010). Differential gene expression in senescing leaves of two silver birch genotypes in response to elevated $\mathrm{CO}_{2}$ and tropospheric ozone. Plant, Cell and Environment 33: 1016-1028. - doi: 10.1111/j.1365-3040.2010. 02123.x

Kronfuß G, Polle A, Tausz M, Havranek WM, Wieser G (1998). Effects of ozone and mild drought stress on gas exchange, antioxidants and chloroplast pigments in current-year needles of young Norway spruce [Picea abies (L.) Karst.]. Trees 12: 482-489. - doi: 10.1007/PL00009730

Lawson T, Oxborough K, Morison JIL, Baker NR (2002). Responses of photosynthetic electron transport in stomatal guard cells and mesophyll cells in intact leaves to light, $\mathrm{CO}_{2}$, and humidity. Plant Physiology 128: 52-62. - doi: 10.1104/ pp.010317

Liu X, Kozovits AR, Grams TEE, Blaschke H, Rennenberg H, Matyssek R (2004). Competition modifies effects of enhanced ozone/carbon dioxide concentrations on carbohydrate and biomass accumulation in juvenile Norway spruce and European beech. Tree Physiology 24: 1045-1055. - doi: 10.1093/treephys/24.9.1045

Luethy-Krause B, Pfenninger I, Landolt W (1990). Effects of ozone on organic acids in needles of Norway spruce and Scots pine. Trees 4: 198-204. - doi: 10.1007/BF00225316
Marenco A, Gouget H, Nédélec P, Pagés JP, Karcher F (1994). Evidence of a long-term increase in tropospheric ozone from Pic du Midi data series: consequences: positive radiative forcing. Journal of Geophysical Research 99: 16617-16632. - doi: 10.1029/94JD00021

Matyssek R, Keller T, Koike T (1993). Branch growth and leaf gas exchange of Populus tremula exposed to low ozone concentrations throughout two growing seasons. Environmental Pollution 79: 1-7. - doi: 10.1016/0269-7491(93) 90170-S

Odanaka S, Bennett AB, Kanayama Y (2002). Distinct physiological roles of fructokinase isozymes revealed by gene-specific suppression of Frk1 and Frk2 expression in tomato. Plant Physiology 129: 1119-1126. - doi: 10.1104/pp. 000703

Olbrich M, Gerstner E, Welzl G, Winkler J, Ernst D (2009). Transcript responses in leaves of ozone-treated beech saplings seasons at an outdoor free air model fumigation site over two growing seasons. Plant and Soil 323: 61-74. doi: 10.1007/s11104-009-0129-4

Örvar BL, McPherson J, Ellis BE (1997). Preactivating wounding response in tobacco prior to high-level ozone exposure prevents necrotic injury. The Plant Journal 11: 203-212. - doi: 10.1046/j.1365-313X.1997.11020203.x

Pell EJ, Schlagnhaufer CD, Arteca RN (1997). Ozone-induced oxidative stress: mechanisms of action and reaction. Physiologia Plantarum 100: 264-273. - doi: 10.1111/j.1399-3054.1997 .tb04782.x

Pritsch K, Ernst D, Fleischmann F, Gayler S, Grams T, Göttlein A, Heller W, Koch N, Lang H, Matyssek R, Munch J, Olbrich M, Scherb H, Stich S, Winkler J, Schloter M (2008). Plant and soil system responses to ozone after 3 years in a Lysimeter study with juvenile beech (Fagus sylvatica L.). Water, Air and Soil Pollution: Focus 8: 139-154. - doi: 10.1007/s11267-007

Ranieri A, Giuntini D, Ferraro F, Nali C, Baldan B, Lorenzini G, Soldatini GF (2001). Chronic ozone fumigation induces alterations in thylakoid functionality and composition in two poplar clones. Plant Physiology and Biochemistry 39: 999-1008. - doi: 10.1016/S0981-9428(01)013201

Reich PB (1983). Effects of low concentrations of $\mathrm{O}_{3}$ on net photosynthesis, dark respiration, and chlorophyll contents in aging hybrid poplar leaves. Plant Physiology 73: 291-296. - doi: 10.1104/pp.73.2.291

Roshchina VV, Roshchina VD (2003). Ozone and plant cell. Kluwer Academic Publisher, Dordrecht, The Netherlands.

Ryang S, Woo S, Kwon S, Kim S, Lee S, Kim K, Lee D (2009). Changes of net photosynthesis, antioxidant enzyme activities, and antioxidant contents of Liriodendron tulipifera under elevated ozone. Photosynthetica 47: 19-25. - doi: 10.1007/ s11099-009-0005-8

Sandermann H (1996). Ozone and plant health. Annual Review of Phytopathology 34: 347-366. doi: 10.1146/annurev.phyto.34.1.347 
Sarkar A, Rakwal R, Agrawal SB, Shibato J, Ogawa Y, Yoshida Y, Agrawal GK, Agrawal M (2010). Investigating the impact of elevated levels of ozone on tropical wheat using integrated phenotypical, physiological, biochemical, and proteomics approaches. Journal of Proteome Research 9: 4565-4584. - doi: 10.1021/ pr1002824

Schloter M, Winkler JB, Aneja M, Koch N, Fleischmann F, Pritsch K, Heller W, Stich S, Grams TE, Gottlein A, Matyssek R, Munch JC (2005). Short term effects of ozone on the plantrhizosphere-bulk soil system of young beech trees. Plant Biology 7: 728-736. - doi: 10.1055/s-
2005-8

Torres NL, Cho K, Shibato J, Hirano M, Kubo A, Masuo Y, Iwahashi H, Jwa NS, Agarwal GK, Rakwal R (2007). Gel-based proteomics reveals potential novel protein markers of ozone stress in leaves of cultivated bean and maize species of Panama. Electrophoresis 28: 4369-4381. - doi: 10.1002/elps.200700219

Vâlcu CM, Schlink K (2006). Efficient extraction of proteins from woody plant samples for two-dimensional electrophoresis. Proteomics 6: 41664175. - doi: 10.1002/pmic. 200500660

Winkler J, Lang H, Graf W, Reth S, Munch J (2009). Experimental set up of field lysimeters for studying effects of elevated ozone and belowground pathogen infection on a plant-soil-system of juvenile beech (Fagus sylvatica L.). Plant and Soil 323: 7-19. - doi: 10.1007/s11104-009-9936$\mathrm{X}$

\section{Supplementary Material}

Appendix 1 - List of peptide sequences of proteins identified by LC-MS/MS (see http://www.sisef.it/iforest/pdf/Kerner_570@, supp101.xls) 